University of Nebraska - Lincoln

DigitalCommons@University of Nebraska - Lincoln

Soil Quality Assessment after Weed-Control Tillage in a No-Till Wheat-Fallow Cropping System

\author{
T. A. Kettler \\ USDA-ARS, tkettler2@unl.edu \\ Drew J. Lyon \\ University of Nebraska-Lincoln, drew.lyon@wsu.edu \\ John W. Doran \\ University of Nebraska-Lincoln, jdoran1@unl.edu \\ W. L. Powers \\ University of Nebraska-Lincoln \\ Walter W. Stroup \\ University of Nebraska-Lincoln, wstroup1@unl.edu
}

Follow this and additional works at: https://digitalcommons.unl.edu/panhandleresext

Part of the Agriculture Commons

Kettler, T. A.; Lyon, Drew J.; Doran, John W.; Powers, W. L.; and Stroup, Walter W., "Soil Quality Assessment after Weed-Control Tillage in a No-Till Wheat-Fallow Cropping System" (2000). Panhandle Research and Extension Center. 6.

https://digitalcommons.unl.edu/panhandleresext/6

This Article is brought to you for free and open access by the Agricultural Research Division of IANR at DigitalCommons@University of Nebraska - Lincoln. It has been accepted for inclusion in Panhandle Research and Extension Center by an authorized administrator of DigitalCommons@University of Nebraska - Lincoln. 


\title{
Soil Quality Assessment after Weed-Control Tillage in a No-Till Wheat-Fallow Cropping System
}

\author{
T. A. Kettler,* D. J. Lyon, J. W. Doran, W. L. Powers, and W. W. Stroup
}

\begin{abstract}
Adoption of reduced-tillage fallow systems in the western USA is limited by winter annual grass weeds such as downy brome (Bromus tectorum L.). Moldboard plowing is an effective means of controlling downy brome in winter wheat (Tritcum aestivum $\mathbf{L}$.)-fallow systems. The purpose of this study was to assess the influence of plowing and secondary tillage operations, for the purpose of weed control, on soil quality attributes of a silt loam soil that had been cropped in a subtill or no-till (NT) winter wheat-fallow system for more than $20 \mathrm{yr}$. Compared with undisturbed NT, downy brome populations in plowed NT decreased 97 and $41 \%$ in the first and third crops following tillage, respectively. Wheat yields in plowed NT treatments were 30 and $9 \%$ greater in the first and third crops following tillage, respectively, compared with undisturbed NT. Soil quality indicators assessed were organic $\mathrm{C}(\mathrm{OC})$, total $\mathrm{N}$, inorganic $\mathrm{N}$, pH, electrical conductivity, bulk density, water infiltration rate, and pore-size distribution. Five years after tillage, soil $\mathrm{OC}$ decline in the $0-$ to $7.5-\mathrm{cm}$ depth was $20 \%$ in plowed compared with undisturbed NT; however, OC increased $15 \%$ in the $7.5-$ to $15-\mathrm{cm}$ depth and was not different in the $0-$ to $30-\mathrm{cm}$ depth. Total soil $\mathbf{N}$ followed similar trends. Soil inorganic $\mathbf{N}$ in plowed NT decreased $37 \%$, and soil pH increased $9 \%$, compared with undisturbed NT, at the $0-$ to $7.5-\mathrm{cm}$ depth. Occasional tillage with the moldboard plow in a reduced- or no-tillage management system will help control winter annual grass weeds, while retaining many of the soil quality benefits of conservation-tillage management.
\end{abstract}

\begin{abstract}
$\mathrm{A}^{\mathrm{D}}$ OPTION OF NO-TILL (NT) MANAGEMENT SYSTEMS by winter wheat producers in Nebraska and other parts of the western USA is currently limited by winter annual grasses such as downy brome (Wicks, 1984, 1997; Lyon and Baltensperger, 1995; Rasmussen, 1995; Wiese et al., 1995). In Nebraska, winter wheat yields were depressed $30 \%$ by downy brome densities of 11 to 22 plants $\mathrm{m}^{-2}$; in Oregon, downy brome densities of $<160$ plants $\mathrm{m}^{-2}$ reduced yields by $40 \%$; and in Idaho, wheat yields were reduced by up to $40 \%$ with 55 to 110 plants $\mathrm{m}^{-2}$ (Wicks, 1984). Selective control of downy brome in winter wheat is difficult since both species have similar life cycles. Crop rotations with at least $2 \mathrm{yr}$ between winter wheat crops are proven effective for downy brome control if plants are kept from producing seed during the non-wheat periods (Lyon and Baltensperger, 1995). Crop rotation, however, is not practiced by many producers due to considerations of climate, machinery, and/or the economics of these management systems. Conservation-tillage practices that emphasize
\end{abstract}

T.A. Kettler and J.W. Doran, USDA-ARS, 119 Keim Hall, Lincoln, NE 68583-0934; D.J. Lyon, Panhandle Research and Extension Center, 4502 Ave. I, Scottsbluff, NE 69361; W.L. Powers, Univ. of Nebraska, 131 Keim Hall, Lincoln, NE 68583; and W.W. Stroup, Univ of Nebraska, 103 Miller Hall, Lincoln, NE 68583. Journal Ser. 12494 of the Agric. Res. Div., Univ. of Nebraska, Lincoln, NE. Received 20 Jan. 1999. *Corresponding author (tkettler@unlinfo.unl.edu).

Published in Soil Sci. Soc. Am. J. 64:339-346 (2000). retaining crop residue on the soil surface to reduce erosion create an environment favorable for downy brome because tillage operations are shallow (or eliminated) and downy brome seeds are not buried deep enough to prevent seedling emergence. Moldboard plowing is an effective means of controlling downy brome in a winter wheat-fallow system (Wicks, 1984). Plowing kills growing downy brome plants and buries seed at depths sufficient to prevent their emergence after germinating. Seeds at a soil depth of $8 \mathrm{~cm}$ or greater generally germinate but do not emerge (Wicks et al., 1971). Most downy brome seed in soil germinates in the first year, and less than $2 \%$ of the seed remains viable in the soil after 3 yr (Wicks, 1997); however, some studies have shown seeds to remain viable for up to $5 \mathrm{yr}$ (Morrow and Stahlman, 1984).

Tillage and cropping system effects on soil chemical and physical characteristics have been documented in many long-term studies (Fenster and Peterson, 1979; Voorhees and Lindstrom, 1984; Wicks et al., 1988; Hill, 1990; Dalal et al., 1991; Karlen et al., 1991; Lyon et al., 1997). It was observed in these studies that frequent use of the moldboard plow causes declines in soil organic $\mathrm{C}(\mathrm{OC})$, decreases in soil structure and aggregation, reductions in water infiltration rates, and increases in soil erosion by wind and water. In two studies of wheatfallow systems in western Nebraska, Doran et al. (1998) reported surface (0 to $7.5 \mathrm{~cm}$ ) soil OC declines of 27 and $40 \%$ for conventional tillage with a spring moldboard plow (PL), and 4 and $20 \%$ for NT after 11 yr of cropping following sod breakout. After $27 \mathrm{yr}$ at these same two sites, surface OC declines were 41 and $48 \%$ for PL, and 18 and $21 \%$ for NT. However, some OC was redistributed to the depth of plowing due to physical movement and perhaps due to enhanced root growth. Thus, declines in soil OC in the 0- to 30.5-cm depth after $27 \mathrm{yr}$ were only 11.7 to $14.4 \%$ for PL, and 7.0 to $11.7 \%$ for NT at these same sites.

There is limited information on the effects of infrequent, intermittent, or periodic moldboard plowing or other inversion tillage used in conjunction with a conservation-tillage or no-tillage management system. In the sub-humid climate of Michigan, Pierce et al. (1994) studied whether soil properties developed under NT in a continuous corn cropping system and on a Capac loam soil (fine-loamy, mixed, mesic Aeric Endoaqualf) were retained or reestablished after a single moldboard plowing. In the year after plowing, bulk density, total porosity, and microporosity $(<24 \mu \mathrm{m}$ pore radii) were decreased, while macroporosity $(>24 \mu \mathrm{m}$ pore radii)

Abbreviations: EC, electrical conductivity; NT, no-till; OC, organic carbon; PL, spring moldboard plow; PSD, pore-size distribution; ST, sub-till. 
increased in plowed compared with nonplowed no-till management. Organic $\mathrm{C}$ was redistributed in the surface $20 \mathrm{~cm}$ by plowing. Four to five years after plowing, most properties had returned to levels of NT, but levels of OC and total $\mathrm{N}$ in the surface 0 to $5 \mathrm{~cm}$ of plowed NT soils remained 10 to $17 \%$ lower than continuous NT.

In the U.S. Central Great Plains, occasional, infrequent moldboard plowing of land under conservationtillage management may effectively control downy brome infestations in winter wheat-fallow cropping systems. However, its use may negate the soil conservation benefits, which are accrued by conservation-tillage management over time (e.g., increased surface residue cover and water infiltration rate, reduced surface runoff, evaporation, and declines in soil OC).

This study assessed (i) the use of the moldboard plow, followed by secondary tillage operations, as an intermittent tool for downy brome control, and (ii) how this tool influenced the soil quality and sustainability of notill and sub-till wheat-fallow production systems.

\section{MATERIALS AND METHODS}

This experiment was conducted as part of a long-term study of tillage management effects in a winter wheat-fallow cropping system, which was undertaken in 1969 at the High Plains Agricultural Laboratory located at Sidney, NE $\left(41^{\circ} \mathrm{N}, 103^{\circ} \mathrm{W}\right)$. Mean annual precipitation at the site is $440 \mathrm{~mm}$, and mean annual temperature is $9^{\circ} \mathrm{C}$. The experimental plots were situated on an Alliance silt loam soil (fine-silty, mixed, superactive, mesic Aridic Argiustoll), formed from mixed loess and loamy calcareous residuum on top of sandstone. The slope of the land is $\approx 1 \%$. Two experimental blocks of four replications each were cropped in alternating years with a wheat-fallow system. The experimental design was a randomized complete block with a split-plot treatment design. Tillage treatments applied to whole-plots were no-till (NT), which entailed no soil disturbance other than seed planting; sub-till (ST), which consisted of sweep plowing at a 10-cm depth three times during the fallow period; and spring moldboard plow (PL) followed by a field cultivator and rod weeder. Nitrogen rates of $0(-\mathrm{N})$ or $45(+\mathrm{N}) \mathrm{kg} \mathrm{N}^{-1}$ were applied to subplots. Nitrogen was broadcast as ammonium nitrate on growing wheat in April. Whole plot dimensions were 8.5 by $72.7 \mathrm{~m}$, and subplots were 4.3 by $72.7 \mathrm{~m}$. Complete field management details are in Fenster and Peterson (1979) and Lyon et al. (1998).

In spring of 1991, plots of the experimental block in fallow (Tillage A) were divided in half by a transect, and the replications were randomly split into moldboard plow $(+\mathrm{pl})$ and no moldboard plow $(-\mathrm{pl})$ regions. The $+\mathrm{pl}$ regions of the ST and NT treatments in each replicate were then moldboard plowed to a $15-\mathrm{cm}$ depth on 8 May, and packed with a mulch treader on 13 May. Subsequent tillage in the $+\mathrm{pl}$ areas included a disking, two chisel treatments, and three treatments with a rod weeder before planting wheat on 17 September. After planting, the experimental plots were all returned to their previous tillage and $\mathrm{N}$ management regimes. In the spring of 1992, the plots of the other experimental block (Tillage B) were divided in half and either plowed or left untouched in the same manner as described above for Tillage A. The resulting experimental design consisted of the original split-plot experiment, with a split-block design superimposed over it. The split block treatments resulted from the imposition of the intermittent moldboard plowing $(+\mathrm{pl}$ and $-\mathrm{pl})$ over the wholeplot tillage treatments of NT and ST. The whole-plot PL treat- ment did not receive intermittent plowing as a split-block treatment, because it was already moldboard-plowed annually. The experimental treatments were analyzed as a $[(2 \times 2+$ 1) $\times 2$ ] factorial design consisting of two whole-plot main tillage treatments (NT and ST) by two split-block tillage treatments $(-\mathrm{pl}$ and $+\mathrm{pl})$, plus one whole-plot main tillage treatment with no split-block (PL), all having a split-plot of two $\mathrm{N}$ levels $(-\mathrm{N}$ and $+\mathrm{N})$. All treatments were considered as fixed effects. The effect of the experimental location (Tillage A and B) was also considered a fixed effect, and the effect of replication within location was considered random. Statistical analysis for the measured soil parameters of the spring-collected soil samples, as well as for the downy brome plant density and wheat harvest yield (described below), was done using an analysis of variance (Table 1) with a mixed-effects model. Contrasts were made comparing the $+\mathrm{pl}$ and $-\mathrm{pl}$ treatments of the NT and ST main tillage treatments, both within and across $\mathrm{N}$ treatments, and comparing the $+\mathrm{pl}$ and $-\mathrm{pl}$ treatments of the NT and ST with the continuous PL treatment, both within and across $\mathrm{N}$ treatment. Procedures that were followed are described in SAS Inst. (1997) and Littell et al. (1996).

Downy brome plant density was measured in the spring of each cropped year. A 1-m square steel frame was randomly placed in two locations of each plot and the number of individual plants inside the frame recorded. The count for each plot was calculated as the average of the counts at each location within the plot. At maturity, wheat was harvested from a 2.4 by $22 \mathrm{~m}$ area in the center of each plot with a combine. The total wet grain mass collected from each plot was weighed and then subsampled for percent moisture and test weight. Harvest yield was then calculated to a standard $120 \mathrm{~g} \mathrm{~kg}^{-1}$ moisture content.

Soil samples were collected in the spring of 1996 and 1997, $5 \mathrm{yr}$ after plowing, on Tillage A and B, respectively. Each sample consisted of a composite of 12 cores collected with a 2 -cm-diam. probe to a $30-\mathrm{cm}$ depth. The $30-\mathrm{cm}$ cores were divided into increments of 0 to $7.5,7.5$ to 15 , and 15 to $30 \mathrm{~cm}$ before compositing. The samples, placed in double plastic bags and securely tied, were left at ambient temperature during transport and kept at $5^{\circ} \mathrm{C}$ after arrival at the laboratory in Lincoln, NE.

Water infiltration rates at Tillage B were measured in the field on 22 July 1997, 1 wk after wheat harvest. Treatments selected for infiltration measurements were NT (with $[+\mathrm{pl}]$ and without $[-\mathrm{pl}]$ plowing) and PL (on plots receiving $45 \mathrm{~kg}$ $\mathrm{ha}^{-1} \mathrm{~N}$ fertilizer). Wheel traffic and nontraffic areas were identified using relative soil resistance to penetration by a 0.3 -cm-diam. brass brazing rod. Three locations were chosen in a nontraffic area of each subplot, $\approx 3 \mathrm{~m}$ apart. A 15 -cm-diam. single-ring infiltrometer was installed to a depth of $7.5 \mathrm{~cm}$ at each location, and infiltration times for each of two $2.5-\mathrm{cm}$ increments of distilled water were recorded. Soil samples were collected to a $7.5-\mathrm{cm}$ depth within a $30-\mathrm{cm}$ radius outside of each infiltration ring using a 7.5-cm-diam. aluminum sampling tube. These soil samples were used to estimate pre-irrigated water content, bulk density, electrical conductivity, and $\mathrm{pH}$ of the soil at each ring location. Analysis of organic $\mathrm{C}$ and $\mathrm{N}$, and inorganic $\mathrm{N}$ were done using procedures described later. The methodologies for measuring water infiltration rates and collecting soil samples are described in Sarrantonio et al. (1996). Since only a subset of the total experimental treatments were chosen for measuring water infiltration and associated soil samples, the working experimental design was a randomized block design with three treatments, four replications, and three sampling units per experimental unit. The statistical analysis for these measurements was performed using SAS 
for analysis of variance, and $T$ tests for means separation (SAS Inst., 1997).

All soil samples collected were weighed in the laboratory to determine total sample mass. Gravimetric water content was determined, and the bulk density of each sample was calculated by dividing its oven-dry mass by the sample volume.

Soil $\mathrm{NO}_{3}^{-}$and $\mathrm{NH}_{4}^{-}-\mathrm{N}$ were determined using the Bremner (1965) method. Soil extracts were analyzed for $\mathrm{NO}_{3}$ and $\mathrm{NH}_{4}$ using the cadmium reduction and indophenol blue procedures described by Keeney and Nelson (1982).

Soil electrical conductivity (EC) and $\mathrm{pH}$ were determined on a 1:1 water/soil mixture using soil at field moisture content and distilled water. Electrical conductivity results were adjusted to an exact 1:1 weight basis. Procedures for EC and $\mathrm{pH}$ determinations are detailed in Sarrantonio et al. (1996), Dahnke and Whitney (1988), and Eckert (1988).

Total soil C and $\mathrm{N}$ content were determined with the Dumas dry combustion technique using an automated Carlo Erba NA $100 \mathrm{C} \& \mathrm{~N}$ analyzer (CE Elantech, Lakewood, NJ), as described by Schepers et al. (1989). The inorganic C content of soil samples with $\mathrm{pH}$ values $>7.2$ (indicating the presence of carbonates) was determined using gas chromatography. Soil inorganic $\mathrm{C}$ was calculated from the amount of $\mathrm{CO}_{2}$ evolved from a soil sample of known mass after adding an $\mathrm{HCl}$ solution in a closed vessel. Soil OC contents were calculated by subtracting inorganic $\mathrm{C}$ content from total $\mathrm{C}$ values.

Soon after wheat harvest in 1996 and 1997, intact soil cores for determining pore-size distribution (PSD) were collected (Uhland, 1950; Baer et al., 1992). Sample cores $7.5 \mathrm{~cm}$ in diam. were collected from between-row non-wheel traffic areas at a depth of 2.5 to $10.2 \mathrm{~cm}$. In 1996, 72 cores were collected from Tillage A: three soil cores from each fertilizer subplot within NT, both $+\mathrm{pl}$ and $-\mathrm{pl}$, and the PL. No differences in PSD were detected between the $-\mathrm{N}$ and $+\mathrm{N}$ treatments in 1996; consequently, the sampling of the $-\mathrm{N}$ treatments was omitted for 1997. Thirty-six cores were collected from Tillage B: three soil cores from each $+\mathrm{N}$ subplot of $\mathrm{NT}+\mathrm{pl}, \mathrm{NT}-\mathrm{pl}$, and PL. The soil cores were collected in the same nontraffic area of each subplot as identified in the infiltration measurements described above. In the laboratory, the cores were placed in pressure cells, then saturated with water from beneath. The cores were desaturated by subjecting to pressures equivalent to $1,2.5,5,7.5,10,12.5,15,17.5,20,25,50,750$, and $100 \mathrm{kPa}$, and the soil moisture-release effluent was collected and measured. Following the $100-\mathrm{kPa}$ pressure step, the water content and bulk density of each core was determined, and the soil moisture contents at each pressure step were calculated relative to saturation (Brooks and Corey, 1964; Baer et al., 1992). The moisture release data was fitted into the Brooks and Corey (1964)

$$
\theta_{\mathrm{R}}=\left(\tau / \tau_{\ell}\right)^{-1}
$$

Where $\theta_{\mathrm{R}}=$ the relative soil water content, $\tau=$ the matric potential, and $\tau_{\mathrm{e}}=$ a matric potential constant for a given soil, called the air-entry value. The soil PSD index $(\lambda)$ is determined by taking the logarithm of both sides of Eq. [1], which yields

$$
\log \left(\theta_{\mathrm{R}}\right)=\lambda \log \left(\tau_{\ell}\right)-\lambda \log (\tau)
$$

where $\lambda \log \left(\tau_{\mathrm{e}}\right)$ is the intercept and $-\lambda$ is the slope of the straight line determined by plotting the $\log \left(\theta_{R}\right)$ vs. $\log (\tau)$. From these relationships, $\lambda$ was calculated as

$$
\lambda=- \text { slope }
$$

Table 1. Skeleton anova for $\{[(2 \times 2)+1] \times 2\}$ experimental treatment design used for intermittent plowing study conducted

\begin{tabular}{|c|c|}
\hline Source $\dagger$ & df \\
\hline $\begin{array}{l}\text { loc } \\
\text { error a (block(loc)) }\end{array}$ & $\begin{array}{l}1 \\
6\end{array}$ \\
\hline $\begin{array}{l}\text { plow } \\
\text { plow } \times \text { loc } \\
\text { error b }(\text { plow } \times \text { block }(\text { loc }))\end{array}$ & $\begin{array}{l}1 \\
1 \\
6\end{array}$ \\
\hline $\begin{array}{l}\text { tillage } \\
\text { tillage } \times \text { loc } \\
\text { error } \mathbf{c}(\text { tillage } \times \text { block } \times \text { loc }))\end{array}$ & $\begin{array}{r}2 \\
2 \\
12\end{array}$ \\
\hline $\begin{array}{l}\text { plow } \times \text { tillage } \\
\text { plow } \times \text { tillage } \times \text { loc } \\
\text { error } d(\text { plow } \times \text { tillage } \times \text { block } \times \text { loc }))\end{array}$ & $\begin{array}{r}2 \\
2 \\
12\end{array}$ \\
\hline $\begin{array}{l}\mathbf{N} \\
\mathbf{N} \times \text { tillage } \\
\mathbf{N} \times \text { tillage } \times \text { loc } \\
\text { error e }(\mathbf{N} \times \text { tillage } \times \text { block }(\mathbf{l o c}))\end{array}$ & $\begin{array}{r}1 \\
2 \\
3 \\
18\end{array}$ \\
\hline $\begin{array}{l}\mathbf{N} \times \text { plow } \\
\mathbf{N} \times \text { tillage } \times \text { plow } \\
\mathbf{N} \times \text { tillage } \times \text { plow } \times \text { loc } \\
\text { error } \mathbf{f}\end{array}$ & $\begin{array}{r}1 \\
2 \\
3 \\
18\end{array}$ \\
\hline
\end{tabular}
on long-term tillage study plots from 1991 to 1997 at Sidney, NE.

$\dagger$ Error term in each partition tests treatment effects in that part of the table.

The PSD index is useful in describing the soil pore-size distribution as a whole. When comparing values of $\lambda$, the larger $\lambda$ implies a more uniform pore size while the smaller $\lambda$ implies a wider range of pore sizes (Corey, 1977). The SAS GLM procedure was used to perform the linear regression and calculate slopes $(\lambda)$ of the log-transformed water-release data from each soil core. Statistical analysis and means separation was conducted in the same manner as described for the water infiltration measurements, above.

\section{RESULTS AND DISCUSSION}

\section{Downy Brome Control and Grain Yield}

Moldboard plowing lowered weed densities in NT management in each of the following three crop years after tillage. Downy brome densities (Table 2) in the $\mathrm{NT}+\mathrm{pl}$ were less than 2 plants $\mathrm{m}^{-2}$ in the first crop after tillage, but increased to yield-limiting levels (Wicks, 1984) of $>35$ plants $\mathrm{m}^{-2}$ in the second crop, and $>65$ plants $\mathrm{m}^{-2}$ in the third crop following tillage. The key to controlling downy brome in winter wheatfallow systems has been identified as preventing the growing plants from producing seed and preventing the introduction of new seed by seeding waste areas with perennial grasses such as smooth brome (Bromus inermis Leyss.) and crested wheatgrass [Agropyron desertorum (Fisch. ex Link) Schult.], which suppresses invasion by downy brome (Wicks, 1997). The rapid return of downy brome infestation was unlikely to be from seed in the soil brought up by tillage since almost total control was achieved in the first crop. The cause of reinfestation was probably due to edge effects: the results of the tillage treatments' close proximity to sources of downy brome seed in adjacent infested areas. Implementing intermittent plowing, or tillage rotation, on a larger field scale would likely reduce exposure of the ecosystem to outside sources of downy brome seed and 
Table 2. Downy brome plant density and winter wheat yield at the Sidney, NE, long-term tillage study for plowed $(+\mathrm{pl})$ and undisturbed $(-\mathrm{pl})$ plots 1,3 , and 5 yr after inversion tillage was used for downy brome control.

\begin{tabular}{|c|c|c|c|c|c|c|}
\hline \multirow{2}{*}{$\begin{array}{l}\text { Tillage } \\
\text { treatment }+\end{array}$} & \multicolumn{3}{|c|}{ Downy brome density } & \multicolumn{3}{|c|}{ Wheat grain yield } \\
\hline & $-\mathbf{p l}$ & $+\mathbf{p l}$ & $\mathbf{S E}_{d} \S$ & $-\mathbf{p l}$ & + pl & $\mathbf{S E}_{d} \S$ \\
\hline & \multicolumn{3}{|c|}{ - plants $\mathbf{m}^{-2}-$} & \multicolumn{3}{|c|}{$-\mathrm{Mg} \mathrm{ha}^{-1}$ - } \\
\hline 1 yr post-tillage & & & & & & \\
\hline No-till & 32 & $1^{* *}$ & 4.4 & 1.0 & $1.3^{* *}$ & 0.06 \\
\hline Sub-till & 4 & 1 & & 0.9 & 1.1** & \\
\hline Plow & $\mathbf{0}$ & & & 1.2 & & \\
\hline \multicolumn{7}{|l|}{3 yr post-tillage } \\
\hline No-till & 68 & $38 * *$ & 8.8 & 2.6 & $2.8^{*}$ & 0.08 \\
\hline Sub-till & 20 & 10 & & 2.5 & $2.9 * *$ & \\
\hline Plow & 1 & & & 3.0 & & \\
\hline \multicolumn{7}{|l|}{5 yr post-tillage } \\
\hline No-till & 113 & $67 * *$ & 11.9 & 1.1 & $1.2 \dagger$ & 0.07 \\
\hline Sub-till & 38 & $16 \dagger$ & & 1.0 & $1.2 * *$ & \\
\hline Plow & 1 & & & 1.6 & & \\
\hline
\end{tabular}

$\dagger, *$,** Contrast of plowed and undisturbed treatment means within main tillage treatment are significant at the $0.10,0.05$, and 0.01 levels, respectively.

+ Mean of experimental treatments at both Tillage $A$ and $B$.

$\S$ Standard error of the difference of the plowed and undisturbed treatment means within main tillage treatment.

lengthen the duration of downy brome control, thus making the need for weed-control tillage less frequent. Reduced weed pressure in the NT + pl treatments were reflected in greater grain yields (Table 2) in the succeeding three crops, compared with the undisturbed NT. Grain yields were also greater in the ST + pl treatments in each of the following three crop years, even though differences in weed populations between $-\mathrm{pl}$ and $+\mathrm{pl}$ were not significant. This difference in yield suggests additional ecosystem factors such as soil fertility were affected by plowing.

Table 3. Soil organic $\mathrm{C}$ and total $\mathrm{N}$ of composite samples collected at the Sidney, NE, long-term tillage study from the plowed $(+\mathrm{pl})$ and undisturbed $(-\mathrm{pl})$ experimental plots $5 \mathrm{yr}$ after inversion tillage was used for downy brome control.

\begin{tabular}{|c|c|c|c|c|c|c|c|c|}
\hline \multirow{2}{*}{$\begin{array}{l}\text { Tillage } \\
\text { treatment }\end{array}$} & \multicolumn{2}{|c|}{$+0 \mathrm{~kg} \mathrm{~N}$} & \multicolumn{2}{|l|}{$+45 \mathrm{~kg} \mathrm{~N}$} & \multicolumn{2}{|c|}{$+0 \operatorname{kg~N}$} & \multicolumn{2}{|l|}{$+45 \mathrm{~kg} \mathrm{~N}$} \\
\hline & $-\mathbf{p l}$ & + pl & $-\mathbf{p l}+\mathbf{p l}$ & $\mathbf{S E}_{d} \S$ & $-\mathbf{p l}$ & + pl & $-\mathbf{p l}+\mathbf{p l}$ & $\mathbf{S E}_{\mathrm{d}} \S$ \\
\hline & \multicolumn{4}{|c|}{- C, Mg ha ${ }^{-1}$ depth $^{-1}-$} & \multicolumn{4}{|c|}{$-\mathrm{N}, \mathrm{Mg} \mathrm{ha}^{-1} \operatorname{depth}^{-1}-$} \\
\hline \multicolumn{9}{|c|}{$\begin{array}{l}\text { 0- to } 7.5-\mathrm{cm} \\
\text { depth }\end{array}$} \\
\hline No-till & 11.4 & $10.0 * *$ & $13.711 .0 * *$ & 0.3 & 1.07 & $0.99 * *$ & $1.291 .08 * *$ & $* 0.03$ \\
\hline Sub-till & 11.0 & 10.5 & $11.910 .7 * *$ & & 1.02 & 0.98 & $1.121 .06 *$ & \\
\hline Plow & 9.2 & & 9.3 & & 0.93 & & 0.98 & \\
\hline \multicolumn{9}{|l|}{$\begin{array}{l}\text { 7.5- to 15- } \\
\text { cm depth }\end{array}$} \\
\hline & 9.7 & $10.6^{* * *}$ & $10.412 .0 * *$ & 0.3 & 0.99 & $1.07 * *$ & $1.061 .18 * *$ & $* 0.03$ \\
\hline Sub-till & 10.0 & $10.5 \dagger$ & $10.211 .0 *$ & & 1.01 & 1.04 & $1.051 .11 *$ & \\
\hline Plow & 9.9 & & 9.8 & & 0.99 & & 1.01 & \\
\hline \multicolumn{9}{|l|}{$\begin{array}{l}\text { 15- to 30- } \\
\text { cm depth }\end{array}$} \\
\hline No-till & 15.2 & 15.4 & 16.916 .6 & 0.8 & 1.67 & 1.70 & 1.831 .84 & 0.07 \\
\hline Sub-till & 14.9 & $16.7^{*}$ & 15.015 .2 & & 1.72 & 1.78 & 1.701 .73 & \\
\hline Plow & 16.1 & & 15.9 & & 1.80 & & 1.80 & \\
\hline \multicolumn{9}{|c|}{$\begin{array}{l}\text { 0- to } 30-\mathrm{cm} \\
\text { depth }\end{array}$} \\
\hline No-till & 36.2 & 35.9 & 41.039 .6 & 1.0 & 3.73 & 3.76 & 4.174.11 & 0.09 \\
\hline Sub-till & 35.9 & $37.8 \dagger$ & 37.136 .9 & & 3.74 & 3.81 & 3.873.91 & \\
\hline Plow & 35.2 & & 35.0 & & 3.72 & & 3.79 & \\
\hline
\end{tabular}

$\dagger, *$, * Contrast of plowed and undisturbed treatment means within main tillage treatment are significant at the $0.10,0.05$, and 0.01 levels, respectively.

$\$$ Mean of experimental treatments at both Tillage $A$ and $B$.

$\S$ Standard error of the difference of the plowed and undisturbed treatment means within main tillage treatment.
Table 4. Soil bulk density and inorganic $\mathrm{N}\left(\mathrm{NO}_{3}+\mathrm{NH}_{4}\right)$ of composite samples collected at the Sidney, NE, long-term tillage study from the plowed $(+\mathrm{pl})$ and undisturbed $(-\mathrm{pl})$ experimental plots $5 \mathrm{yr}$ after inversion tillage was used for downy brome control.

\begin{tabular}{|c|c|c|c|c|c|c|c|c|}
\hline \multirow[b]{3}{*}{ Tillage treatment $\$$} & \multirow{2}{*}{\multicolumn{3}{|c|}{ Bulk density§ }} & \multicolumn{5}{|c|}{ Inorganic $\mathrm{N}\left(\mathrm{NO}_{3}+\mathrm{NH}_{4}\right)$} \\
\hline & & & & \multicolumn{2}{|c|}{$+0 \mathbf{k g ~ N ~ h a}{ }^{-1}$} & \multicolumn{2}{|c|}{$+45 \mathrm{~kg} \mathrm{~N} \mathrm{ha}^{-1}$} & \multirow[b]{2}{*}{$\mathbf{S E}_{\mathrm{d}} \mathrm{I}$} \\
\hline & $-\mathbf{p l}$ & $+\mathbf{p l}$ & $\mathbf{S E}_{\mathrm{d}} \mathrm{II}$ & I $-\mathbf{p l}$ & $+\mathbf{p l}$ & $-\mathbf{p l}$ & $+\mathbf{p l}$ & \\
\hline & \multicolumn{3}{|c|}{$\mathrm{Mg} \mathrm{m}^{-3}$} & \multicolumn{4}{|c|}{$\longrightarrow \mathrm{kg} \mathrm{ha}^{-1}$} & \\
\hline \multicolumn{9}{|c|}{0 - to $7.5-\mathrm{cm}$ depth } \\
\hline No-till & 1.24 & $1.30 *$ & $* 0.03$ & 3.8 & 2.6 & 21.5 & $13.5^{* * *}$ & 2.9 \\
\hline Sub-till & 1.27 & 1.31 & & 4.6 & 3.9 & 25.6 & $20.6 \dagger$ & \\
\hline Plow & 1.33 & & & 9.9 & & 28.8 & & \\
\hline \multicolumn{9}{|c|}{ 7.5- to $15-\mathrm{cm}$ depth } \\
\hline No-till & 1.43 & 1.44 & 0.02 & 1.4 & 1.8 & 2.4 & 2.8 & 0.8 \\
\hline Su & 1.44 & 1.47 & & 1.5 & 1.5 & 4.4 & 4.4 & \\
\hline Plow & 1.41 & & & 6.5 & & 10.3 & & \\
\hline \multicolumn{9}{|c|}{ 15- to 30-cm depth } \\
\hline No-till & 1.37 & 1.37 & 0.01 & 3.4 & 3.5 & 6.9 & 7.4 & 1.1 \\
\hline Sub-till & 1.36 & 1.34 & & 3.2 & 3.9 & 9.1 & $11.6^{*}$ & \\
\hline Plow & 1.37 & & & 10.1 & & 14.5 & & \\
\hline \multicolumn{9}{|c|}{0 - to $30-\mathrm{cm}$ depth } \\
\hline No-till & 1.35 & $1.37 \dagger$ & $\dagger 0.01$ & 8.3 & 8.1 & 30.5 & 24.1 & 4.3 \\
\hline Sub-ti & 1.35 & 1.37 & & 9.0 & 9.7 & 38.8 & 36.8 & \\
\hline Plow & 1.37 & & & 26.4 & & 53.6 & & \\
\hline
\end{tabular}

$\dagger, *, * *$ Contrast of plowed and undisturbed treatment means within main tillage treatment are significant at the $0.10,0.05$, and 0.01 levels, respectively.

+ Mean of experimental treatments at both Tillage $A$ and $B$.

$\S$ Mean of combined +0 and $+45 \mathrm{~kg} \mathrm{~N} \mathrm{ha}^{-1}$ samples.

II Standard error of the difference of the plowed and undisturbed treatment means within main tillage treatment.

\section{Organic Carbon and Nitrogen}

Soil OC content and distribution for spring-collected samples (Table 3) differed due to plowing in the NT and ST treatments $5 \mathrm{yr}$ after plowing. Organic $\mathrm{C}$ contents at the 0 - to $7.5-\mathrm{cm}$ depth of $\mathrm{NT}+\mathrm{pl}$ were lower than NT - pl by 12 and $20 \%$ for $-\mathrm{N}$ and $+\mathrm{N}$ treatments, respectively. These results corresponded to those of 0 - to 7.5-cm depth soil samples collected with the water infiltration measurements (data not shown), where the NT $+\mathrm{pl},+\mathrm{N}$ treatment was $22 \%$ lower in OC than the NT $-\mathrm{pl},+\mathrm{N}$ treatment. Declines in $\mathrm{OC}$ at the $0-$ to $7.5-\mathrm{cm}$ depth were nearly matched by OC increases at the 7.5- to $15-\mathrm{cm}$ depth of 9 and $15 \%$ for these same treatments. Net change of OC due to plowing in NT in the 0 - to $15-\mathrm{cm}$ depth range was $-0.5 \mathrm{Mg} \mathrm{ha}{ }^{-1}(-2.4 \%)$ for the $-\mathrm{N}$, and $-1.1 \mathrm{Mg} \mathrm{ha}^{-1}(-4.6 \%)$ for the $+\mathrm{N}$ treatment. Soil OC of NT was unchanged by plowing in either $\mathrm{N}$ treatment at the 15 - to $30-\mathrm{cm}$ depth. Changes in OC in the ST treatments were similar to those of NT, with declines of OC in surface soil and increases in the 7.5- to $15-\mathrm{cm}$ and 15 - to $30-\mathrm{cm}$ depths. In the 0 - to $30-\mathrm{cm}$ depth sampled, which includes the zone of tillage and main plant rooting zone, there was no detectable effect of plowing on OC levels in NT, or ST $+\mathrm{N}, 5 \mathrm{yr}$ after tillage. Organic $\mathrm{C}$ in the $\mathrm{ST}-\mathrm{N}$ treatment was $1.8 \mathrm{Mg} \mathrm{ha}^{-1}(5 \%)$ greater in the $+\mathrm{pl}$ compared with the - pl. Plowing appears to have redistributed the OC, which had become concentrated at the soil surface after $21 \mathrm{yr}$ of NT or ST management, through the 0 - to $15-\mathrm{cm}$ tillage zone, creating a more uniform OC distribution.

Changes in soil total $\mathrm{N}$ (Table 3) generally mirrored those of $\mathrm{OC}$, and the overall effects of the plowing treatment in NT and ST were the same, with total N 
content of surface soil reduced, total $\mathrm{N}$ content of the $7.5-$ to $15-\mathrm{cm}$ depth increased, and total $\mathrm{N}$ content of the $0-$ to $30-\mathrm{cm}$ depth remaining unchanged. These results are similar to the findings of Pierce et al. (1994) who found that 4 to $5 \mathrm{yr}$ after plowing, OC and total $\mathrm{N}$ at the 0 - to $5-\mathrm{cm}$ depth of NT + pl were lower than NT - pl, but were not different at the 5- to $20-\mathrm{cm}$ depths.

\section{Bulk Density}

Bulk density (Table 4) increased in $+\mathrm{pl}$ at the 0 - to $7.5-\mathrm{cm}$ depth of NT, but not in the ST treatment. The - pl treatments of NT and ST were different from the continuous PL, while the + pl treatments were not, indicating that soil bulk density was still affected by tillage $5 \mathrm{yr}$ after it was implemented. The bulk densities found in the NT $+\mathrm{pl}$ and NT $-\mathrm{pl}$ treatments are similar to those predicted using Rawls' (Rawls, 1983) method of bulk density estimation based upon soil particle size percentages and organic matter content. The increase in bulk density at the $0-$ to $7.5-\mathrm{cm}$ depth in the NT $+\mathrm{pl}$ plots can be attributed to the decrease in organic $\mathrm{C}$ that had accumulated at the soil surface after $21 \mathrm{yr}$ of NT management. The trend for lower soil bulk density to be found in long-term NT rather than in other tillage treatments, as seen in this study, contrasts with the findings by Pierce et al. (1994), who measured greater bulk density values in NT, reduced bulk density with conventional (PL) tillage, and no detectable residual effects on bulk density 4 and 5 yr after plowing. This contrast may be due to differences in soil type and organic matter content, cropping system, and/or climate.

\section{Inorganic Nitrogen}

Differences in surface inorganic $\mathrm{N}\left(\mathrm{NO}_{3}-\mathrm{N}\right.$ and $\mathrm{NH}_{4}-\mathrm{N}$ ) content were apparent $5 \mathrm{yr}$ after tillage. Total inorganic $\mathrm{N}$ content $\left(\mathrm{NO}_{3}-\mathrm{N}+\mathrm{NH}_{4}-\mathrm{N}\right.$, Table 4) of surface soil differed between the $-\mathrm{pl}$ and $+\mathrm{pl}$ of the $+\mathrm{N}, \mathrm{NT}$, and ST plots, with -pl being $8.0 \mathrm{~kg} \mathrm{ha}^{-1}(36 \%)$ higher in NT, and $5.0 \mathrm{~kg} \mathrm{ha}^{-1}(20 \%)$ higher in ST. Sur- face soil samples, collected with the water infiltration measurements after harvest in 1997 at Tillage B, also differed in $\mathrm{NO}_{3}-\mathrm{N}$ content between the $-\mathrm{pl}$ and $+\mathrm{pl}$ treatments of NT, with $-\mathrm{pl}$ being $2.8 \mathrm{~kg} \mathrm{ha}^{-1}(40 \%)$ higher than $+\mathrm{pl}$ (data not shown). However, in the lower soil depths of the composite samples, there were no differences in inorganic N with NT; and averaged over the 0 - to $30-\mathrm{cm}$ depth there was no difference between the $-\mathrm{pl}$ and $+\mathrm{pl}$ in either NT or ST. This suggests that inorganic $\mathrm{N}$ may have been redistributed by tillage and became less stratified at the soil surface. There were no differences in inorganic $\mathrm{N}$ content between the $-\mathrm{pl}$ and $+\mathrm{pl}$ for the ST treatments at the 7.5- to $15-\mathrm{cm}$ depth, but the $\mathrm{NO}_{3}-\mathrm{N}$ and total inorganic $\mathrm{N}$ contents at the 15- to $30-\mathrm{cm}$ depth were $2.5 \mathrm{~kg} \mathrm{ha}^{-1}(20 \%)$ higher in the $+\mathrm{N}+\mathrm{pl}$ treatment. This may be a result of the mineralization of organic $\mathrm{N}$ redistributed by plowing, which is still detectable after $5 \mathrm{yr}$.

When measured at the $0-$ to $30-\mathrm{cm}$ depth, the PL treatments were higher in inorganic $\mathrm{N}$ than at all measured soil depths of all other treatments-at least $65 \%$ higher in nonfertilized soil $(-\mathrm{N})$ and at least $40 \%$ higher in fertilized $(+N)$ treatments. This may reflect higher rates of organic $\mathrm{N}$ mineralization, which are known to occur with conventional tillage (Doran, 1980; Doran and Linn, 1994). The redistribution of organic and inorganic $\mathrm{N}$ may be a factor in the yield increases seen in the $+\mathrm{pl}$ treatments, and may be due to the placement of plant nutrients at a greater soil depth, more accessible to where plant roots grow when seeking water during periods of moisture stress.

\section{Soil pH and Electrical Conductivity}

Soil $\mathrm{pH}$ of 0 - to $7.5-\mathrm{cm}$ depth samples (Table 5) taken in the NT treatments were higher in + pl compared with $-\mathrm{pl}$, in the $+\mathrm{N}$ treatments, and also when measured across $\mathrm{N}$ levels (data not shown). There were no $\mathrm{pH}$ differences due to plowing in the $7.5-$ to $15-\mathrm{cm}$ or 15 - to $30-\mathrm{cm}$ depths of the NT. These results concur with the findings of Follett and Petersen (1988) who found that

Table 5. Soil pH and electrical conductivity (EC) of composite samples collected at the Sidney, NE, long-term tillage study from the plowed $(+\mathrm{pl})$ and undisturbed $(-\mathrm{pl})$ experimental plots $5 \mathrm{yr}$ after inversion tillage was used for downy brome control.

\begin{tabular}{|c|c|c|c|c|c|c|c|c|c|c|}
\hline \multirow[b]{2}{*}{ Tillage treatment $\$$} & \multicolumn{2}{|c|}{0 kg N ha ${ }^{-1}$} & \multicolumn{2}{|c|}{$45 \mathrm{~kg} \mathrm{~N} \mathrm{ha}^{-1}$} & \multirow[b]{2}{*}{$\mathbf{S E}_{\mathrm{d}}$ II } & \multicolumn{2}{|c|}{0 kg N ha ${ }^{-1}$} & \multicolumn{2}{|c|}{$45 \mathrm{~kg} \mathrm{~N} \mathrm{ha}^{-1}$} & \multirow[b]{2}{*}{$\mathbf{S E}_{\mathrm{d}} \mathrm{II}$} \\
\hline & $-\mathbf{p l}$ & $+\mathbf{p l}$ & $-\mathbf{p l}$ & $+\mathbf{p l}$ & & $-\mathbf{p l}$ & $+\mathbf{p l}$ & $-\mathbf{p l}$ & $+\mathbf{p l}$ & \\
\hline & 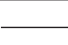 & 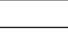 & 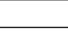 & {[} & 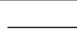 & $-\mathbf{E}$ & $1^{-1}$ & - & & \\
\hline \multicolumn{11}{|l|}{ 0- to $7.5-\mathrm{cm}$ depth } \\
\hline No-till & 6.30 & 6.53 & 5.85 & $6.38 * *$ & 0.15 & 0.11 & 0.12 & 0.17 & 0.18 & 0.02 \\
\hline Sub-till & 6.65 & 6.85 & 6.30 & 6.49 & 0.18 & 0.17 & 0.22 & $\dagger 0.18 \dagger$ & & \\
\hline Plow & 6.91 & & 6.87 & & & 0.19 & & 0.26 & & \\
\hline \multicolumn{11}{|l|}{ 7.5- to $15-\mathrm{cm}$ depth } \\
\hline No-till & 6.64 & 6.54 & 6.50 & 6.25 & 0.18 & 0.09 & 0.09 & 0.09 & 0.12 & 0.02 \\
\hline Sub-till & 6.73 & 6.86 & 6.50 & 6.54 & & 0.14 & 0.15 & 0.12 & 0.15 & \\
\hline Plow & 6.92 & & 6.98 & & & 0.16 & & 0.20 & & \\
\hline \multicolumn{11}{|l|}{ 15- to 30-cm depth } \\
\hline No-till & 7.18 & 6.99 & 7.04 & 7.27 & 0.19 & 0.16 & 0.16 & 0.16 & 0.20 & 0.03 \\
\hline Sub-till & 7.45 & 7.48 & 7.31 & 7.31 & & 0.20 & 0.20 & 0.18 & 0.20 & \\
\hline Plow & 7.39 & & 7.41 & & & 0.19 & & 0.24 & & \\
\hline \multicolumn{11}{|l|}{ 0- to 30-cm depth } \\
\hline No-till & 6.83 & 6.75 & 6.62 & 6.78 & 0.15 & 0.13 & 0.13 & 0.15 & 0.17 & 0.02 \\
\hline Sub-till & 7.08 & 7.16 & 6.87 & 6.91 & & 0.18 & 0.18 & 0.18 & 0.18 & \\
\hline Plow & 7.15 & & 7.17 & & & 0.19 & & 0.24 & & \\
\hline
\end{tabular}

$\dagger, *$, * Contrast of plowed and undisturbed treatment means within main tillage treatment are significant at the $0.10,0.05$, and 0.01 levels, respectively + Mean of experimental treatments at both Tillage $\mathbf{A}$ and $\mathbf{B}$.

$\S$ Standard error of the difference of the plowed and undisturbed treatment means within main tillage treatment. 
NT management in wheat-fallow systems resulted in lower surface soil $\mathrm{pH}$ compared with tilled soils, and that the effect was greater when $\mathrm{N}$ fertilizers were surface applied (broadcast). Rasmussen and Rhode (1989) also found that soil $\mathrm{pH}$ was affected by tillage and $\mathrm{N}$ fertilizers. They concluded that differences in $\mathrm{pH}$ with depth were related to the degree of soil mixing by tillage. Less tillage often leads to lower surface $\mathrm{pH}$, and greater stratification of $\mathrm{pH}$ with depth. Tillage of NT plots in this experiment increased surface soil $\mathrm{pH}$ and reduced vertical $\mathrm{pH}$ stratification. In the ST treatment, soil $\mathrm{pH}$ was not different due to plowing at any depth. The main effect of plowing on soil $\mathrm{pH}$, across both NT and ST, was significant for the $0-$ to $7.5-\mathrm{cm}$ depth (data not shown), with + pl being higher than - pl. Both NT and ST treatments, which leave plant residues at or near the soil surface, were of lower $\mathrm{pH}$ than the PL treatments at the 0 - to $7.5-\mathrm{cm}, 7.5-$ to $15-\mathrm{cm}$, and $0-$ to $30-\mathrm{cm}$ depths. This is consistent with studies that have shown that inversion tillage (moldboard plowing) distributes soil acidity throughout the tillage zone and mixes the acidified surface soil with more alkaline soil from below the 7.5-cm depth (Follett and Peterson, 1988; Rasmussen and Rhode, 1989; Logan et al., 1991). Increases in surface soil $\mathrm{pH}$ due to tillage in this experiment were likely due to the mixing of surface soil with subsurface soil containing carbonates. Measurements of EC showed a nonsaline soil condition $\left(\mathrm{EC}<1.1 \mathrm{dS} \mathrm{m}^{-1}\right.$ ) for all treatments (Smith and Doran, 1996). Measured EC values did not reflect the inorganic $\mathrm{N}$ differences between NT treatments described above. While there were no EC differences attributable to plowing in NT at any depth or $\mathrm{N}$ level, at the $0-$ to $7.5-\mathrm{cm}$ depth of $\mathrm{ST}+\mathrm{N}$, EC was lower in $+\mathrm{pl}$ than $-\mathrm{pl}$ (Table 5), a difference which was also seen in inorganic $\mathrm{N}$ measurements. At the 7.5- to $15-\mathrm{cm}$ and $15-$ to $30-\mathrm{cm}$ depths of ST, there were no differences in EC between $-\mathrm{pl}$ and + pl either within or across $\mathrm{N}$ level.

\section{Pore-size Distribution}

Differences seen in the bulk density of surface samples between NT $-\mathrm{pl}$ and $\mathrm{NT}+\mathrm{pl}$ were not seen in the pore-size distribution (PSD) cores, where no differences in bulk density or PSD index were found (Table 6). This may be due to the cores being sampled across the 2.5 - to $10-\mathrm{cm}$ depth, thus, excluding the top 0 - to $2.5-\mathrm{cm}$ inter-

Table 6. In-field water infiltration and pore-size distribution index $(\lambda)$ with soil bulk density for intact soil cores $(2.5$ to 10 cm depth) collected from the Sidney, NE, long-term tillage plots $5 \mathrm{yr}$ after inversion tillage was used for downy brome control.

\begin{tabular}{|c|c|c|c|c|}
\hline \multirow[b]{2}{*}{$\begin{array}{l}\text { Tillage } \\
\text { treatment } \dagger\end{array}$} & \multirow[b]{2}{*}{$\begin{array}{c}\text { Bulk } \\
\text { density }\end{array}$} & \multirow{2}{*}{$\begin{array}{c}\text { Pore-size } \\
\text { distribution } \\
\text { index }\end{array}$} & \multicolumn{2}{|c|}{ Infiltration time } \\
\hline & & & $\begin{array}{c}1 \mathrm{st} \\
2.5 \mathrm{~cm} \mathrm{H}_{2} \mathrm{O}\end{array}$ & $\begin{array}{l}\text { 2nd } \\
2.5 \mathrm{~cm} \mathrm{H} \mathrm{H}_{2} \mathrm{O}\end{array}$ \\
\hline & $\mathrm{g} \mathrm{cm}^{-3}$ & $\lambda$ & - & \\
\hline NT-pl & $1.25 a$ & $0.147 a$ & $5.5 \mathrm{a}$ & $12.9 \mathrm{~b}$ \\
\hline $\mathbf{N T}+\mathbf{p l}$ & $1.24 a$ & $0.150 \mathrm{a}$ & 3.4a & 27.8a \\
\hline & $1.26 a$ & $0.155 a$ & $5.5 a$ & 21.7ab \\
\hline $\mathbf{S E}_{\mathrm{d}} \S$ & 0.038 & 0.010 & 1.62 & 8.46 \\
\hline
\end{tabular}

$\dagger \mathbf{N T}-\mathbf{p l}=$ no-till, undisturbed; $\mathbf{N T}+\mathbf{p l}=$ no-till, plowed; $\mathbf{P L}=$ continuous plow; all measurements taken from $+45 \mathrm{~kg} \mathrm{~N} \mathrm{ha}^{-1}$ treatments.

$\$$ Values followed by the same letter within each column are not signifi-

cantly different $(=0.10)$.

$\S$ Standard error of the difference between treatment means. val, which in NT has the greatest accumulation of organic matter. Rawls (1983) correlated soil organic matter content inversely with bulk density, thus the 2.5 - to $10-\mathrm{cm}$ depth range missed the surface interval, which showed a decrease in OC content in the NT $+\mathrm{pl}$, and a corresponding increase in soil bulk density. Pore-size distribution of $\mathrm{NT}+\mathrm{pl}$ appears to have returned to its pre-plowed condition, as indicated by the similarity of the $-\mathrm{pl}$ and $+\mathrm{pl} \lambda$ values. Using the PSD index as an indicator, it appears there is no detectable effect of plowing on soil structure $5 \mathrm{yr}$ after return to NT management.

\section{Water Infiltration}

No differences were seen in infiltration times for the first $2.5 \mathrm{~cm}$ of applied water (Table 6). Infiltration times for the second $2.5 \mathrm{~cm}$ of applied water were faster for the NT $-\mathrm{pl}$ than for the NT $+\mathrm{pl}$ or the continuous PL treatments. The NT + pl and PL treatment infiltration times were nearly double that of the NT - pl. However, the average total infiltration time of $31.2 \mathrm{~min}$ for $5.1 \mathrm{~cm}$ of water measured in the NT $+\mathrm{pl}$ treatments would not likely lead to any frequent or consistent rainfall losses to surface runoff or to soil erosion due to water forces, since the climatic records for the site (Hershfield, 1961) indicate that a $5.1-\mathrm{cm}$ rainfall in $30 \mathrm{~min}$ would occur just once every $50 \mathrm{yr}$, and such an event in $1 \mathrm{~h}$ could be expected about once every $20 \mathrm{yr}$. Soil water infiltration times for the two $2.5-\mathrm{cm}$ increments of applied water combined convert to infiltration rates of 96 and $110 \mathrm{~mm}$ $\mathrm{hr}^{-1}$ in the NT $+\mathrm{pl}$ and PL treatments, respectively, and $163 \mathrm{~mm} \mathrm{hr}^{-1}$ in the NT - pl treatment. Even though the $\mathrm{NT}+\mathrm{pl}$ infiltration rate is $67 \mathrm{~mm} \mathrm{hr}^{-1}(41 \%)$ less than $\mathrm{NT}+$ pl, given considerations of local climate and precipitation patterns it appears that tillage effects on the water infiltration rate will not be a consistent limiting factor to rainfall retention by this soil in these cropping systems. These results agree with those of Mielke et al. (1984) who found similar infiltration relationships at this same site.

\section{CONCLUSIONS}

Soil quality indicators measured $5 \mathrm{yr}$ after tillage showed detectable changes in content and distribution of organic matter, $\mathrm{pH}$, and plant nutrients, which may benefit plant growth and grain yield. Soil pore-size distribution index measurements indicated no differences in soil structure or bulk density in the near-surface soil, suggesting that the method of determining the PSD index was not sensitive enough to detect differences in this system. Water infiltration times indicated that the $\mathrm{NT}+$ pl treatment was still affected by tillage after $5 \mathrm{yr}$. Even though infiltration times were slower in the NT $+\mathrm{pl}$, long-term climatic records indicate that surface runoff of precipitation could be expected to occur only once in $20 \mathrm{yr}$ or more, indicating no significant loss of water to runoff or of soil erosion by water transport. Results of this study showed that OC in surface soil was redistributed within the top $30 \mathrm{~cm}$ of the soil profile by plowing. While declines in $\mathrm{OC}$ at the $0-$ to $7.5-\mathrm{cm}$ depth 
were as high as $20 \%$ in NT, OC levels in the $7.5-$ to $15-\mathrm{cm}$ depth were increased, and in the $0-$ to $30-\mathrm{cm}$ depth were not different $5 \mathrm{yr}$ after tillage. Despite the reduction in $\mathrm{OC}$ and total $\mathrm{N}$ in the surface soil, soil quality in the $0-$ to $30-\mathrm{cm}$ depth would appear to be unchanged or improved by the redistribution of surface accumulations of the soil organic matter throughout the tillage zone. The redistribution of soil organic matter may have provided some short-term soil quality benefits, as evidenced by increased yields in the plowed treatments in each of the succeeding three crops. Though some of the yield increase in the plowed plots may be attributed to decreased competition from downy brome, the yield increase in ST, where there were no differences in downy brome plant density, must be due to changes in soil wrought by plowing.

Inclusion of intermittent plowing or tillage rotation to control annual grass in conservation-tillage wheatfallow systems may have mixed effects upon soil quality and system sustainability. Positive affects of plowing included greatly reduced downy brome population, an increase in grain yield, reduced stratification of soil inorganic $\mathrm{N}$, increased inorganic $\mathrm{N}$ mineralized at the 7.5to $15-\mathrm{cm}$ and $15-$ to $30-\mathrm{cm}$ depths, and increased surface soil $\mathrm{pH}$. Surface soil quality as related to surface residue cover and organic matter concentrations appear to be negatively affected by implementing inversion tillage on the NT and ST systems. In the Pacific Northwest winter wheat-growing region, Zuzel et al. (1990) found that surface residue cover had a greater effect on the soil water infiltration rate than did type of tillage management (plow, sweep, or disk).

The moldboard plow should be used with caution. Even though some short-term benefits were seen in this study, extensive literature exists documenting the deleterious and potentially disastrous effects of its overuse on soil quality. Tillage causes loss of soil water in the tillage zone, and loss of surface cover leaves the soil bare in the year of tillage, possibly resulting in loss of soil to wind or water erosion. However, the soil exposure to erosive environmental elements is less with tillage rotation than with annual tillage.

\section{REFERENCES}

Baer, J.U., W.L. Powers, P.J. Shea, and C.L. Stueffer-Powell. 1992 Pore size distribution index as an indicator of atrazine movement in a Crete silt loam soil. Soil Sci. 154:377-386.

Bremner, J.M. 1965. Inorganic forms of nitrogen. p. 1179-1237. In C.A. Black et al. (ed.) Methods of soil analysis. Part 2. 1st ed. Agron. Monogr. 9. ASA, Madison, WI.

Brooks, R.H., and A.T. Corey. 1964. Hydraulic properties of porous media. Colorado State Univ. Hydrol. Paper 3. Colorado State Univ., Fort Collins.

Corey, A.T. 1977. Mechanics of heterogenous fluids in porous media. Water Resour. Publ., Fort Collins, CO.

Dahnke, W.C., and D.A. Whitney. 1988. Measurement of soil salinity. p. 32-33. In W.C. Dahnke (ed.) Recommended chemical soil test procedures for the north central region. North Cen. Regional North Dakota Agric. Exp. Stn., North Dakota State Univ., Fargo, ND.

Dalal, R.C., P.A. Henderson, and J.M. Glasby. 1991. Organic matter and microbial biomass in a vertisol after $20 \mathrm{yr}$ of zero-tillage. Soil Biol. Biochem. 23:435-441.

Doran, J.W. 1980. Soil microbial and biochemical changes associated with reduced tillage. Soil Sci. Soc. Am. J. 44:765-771.
Doran, J.W., E.T. Elliott, and K. Paustian. 1998. Soil microbial activity, nitrogen cycling, and long-term changes in organic carbon pools as related to fallow tillage management. Soil Tillage Res. 49:3-18.

Doran, J.W., and D.M. Linn. 1994. Microbial ecology of conservation management systems. p. 1-27. In J.L. Hatfield and B.A. Stewart (ed.) Soil biology: Effects on soil quality. Advances in soil science. Lewis Publ., Boca Raton, FL.

Eckert, D.J. 1988. Recommended $\mathrm{pH}$ and lime requirement tests. p. 29-31. In W.C. Dahnke (ed.) Recommended chemical soil test procedures for the north central region. North Cen. Regional North Dakota Agric. Exp. Stn., North Dakota State Univ., Fargo, ND.

Fenster, C.R., and G.A. Peterson. 1979. Effects of no-tillage fallow as compared to conventional tillage in a wheat-fallow system. Nebraska Agric. Exp. Stn. Res. Bull. 289. Inst. Agric. Nat. Resour., Univ. Nebraska, Lincoln, NE.

Follett, R.F., and G.A. Peterson. 1988. Surface soil nutrient distribution as affected by wheat-fallow tillage systems. Soil Sci. Soc. Am. J. 52:141-147.

Hershfield, D.M. 1961. Rainfall frequency atlas of the United States, for durations from 30 minutes to 24 hours, and return periods from 1 to 100 years. Weather Bureau Tech. Paper 40. Dep. Commerce, U.S. Govt. Print. Office, Washington, DC.

Hill, R.L. 1990. Long-term conventional and no-tillage effects on selected soil physical properties. Soil Sci. Soc. Am. J. 54:161-166.

Karlen, D.L., E.C. Berry, and T.S. Colvin. 1991. Twelve-year tillage and crop rotation effects on yields and soil chemical properties in northeast Iowa. Commun. Soil Sci. Plant Anal. 22:1985-2003.

Keeney, D.R., and D.W. Nelson. 1982. Nitrogen-inorganic forms. p. 672-682. In A.L. Page et al. (ed.) Methods of soil analysis. Part 2. 2nd ed. Agron. Monogr. 9. ASA and SSSA, Madison, WI.

Littell, R.C., G.A. Milliken, W.W. Stroup, and R.D. Wolfinger. 1996. SAS system for mixed models. SAS Inst., Cary, NC.

Logan, T.J., R. Lal, and W.A. Dick. 1991. Tillage systems and soil properties in North America. Soil Tillage Res. 20:241-270.

Lyon, D.J., and D.D. Baltensperger. 1995 Cropping systems control winter annual grass weeds in winter wheat. J. Prod. Agric. 8: $535-539$.

Lyon, D.J., C.A. Monz, R.E. Brown, and A.K. Metherell. 1997. Soil organic matter changes over two decades of winter wheat-fallow cropping in Western Nebraska. p. 343-351. In E.A. Paul et al. (ed.) Soil organic matter in temperate agroecosystems. CRC Press, Boca Raton, FL.

Lyon, D.J., W.W. Stroup, and R.E. Brown. 1998. Crop production and soil water storage in long-term winter wheat-fallow tillage experiments. Soil Tillage Res. 49:19-28.

Mielke, L.N., W.W. Wilhelm, K.A. Richards, and C.R. Fenster. 1984 Soil physical characteristics of reduced tillage in a wheat-fallow system. Trans. ASAE 27:1724-1728.

Morrow, L.A., and P.W. Stahlman. 1984. The history and distribution of downy brome (Bromus tectorum) in North America. Weed Sci. 32(Suppl.)1:2-6.

Pierce, F.J., M.C. Fortin, and M.J. Staton. 1994. Periodic plowing effects on soil properties in a no-till farming system. Soil Sci. Soc. Am. J. 58:1782-1787.

Rasmussen, P.E. 1995. Effects of fertilizer and stubble burning on downy brome competition in winter wheat. Commun. Soil Sci. Plant Anal. 26:951-960.

Rasmussen, P.E., and C.R. Rhode. 1989. Soil acidification from ammonium-nitrogen fertilization in moldboard plow and stubble-mulch wheat-fallow tillage. Soil Sci. Soc. Am. J. 53:119-122.

Rawls, W.J. 1983. Estimating soil bulk density from particle size analysis and organic matter content. Soil Sci. 135(2):123-125.

SAS Inst. 1997. SAS/STAT Software: Changes and enhancements through release 6.12. p. 571-702. SAS Inst., Cary, NC.

Sarrantonio, M., J.W. Doran, M.A. Liebig, and J.J. Halvorson. 1996. On-farm assessment of soil quality and health. p. 83-106. In J.W. Doran and A.J. Jones (ed.) Methods for assessing soil quality. SSSA Spec. Publ. 49. SSSA, Madison, WI.

Schepers, J.S., D.D. Francis, and M.T. Thompson. 1989. Simultaneous determination of total $\mathrm{C}$, total $\mathrm{N}$, and ${ }^{15} \mathrm{~N}$ on soil and plant material Commun. Soil Sci. Plant Anal. 20:949-959.

Smith, J.L., and J.W. Doran. 1996. Measurement and use of pH and electrical conductivity for soil quality analysis. p.169-186. In J.W. Doran and A.J. Jones (ed.) Methods for assessing soil quality. SSSA Spec. Publ. 49. SSSA, Madison, WI. 
Uhland, R.R. 1950. Physical properties of soil as modified by crops and management. Soil Sci. Soc. Am. Proc. 14:361-366.

Voorhees, W.B., and M.J. Lindstrom. 1984. Long-term effects of tillage method on soil tilth independent of wheel traffic compaction. Soil Sci. Soc. Am. J. 48:152-156.

Wicks, G.A. 1984. Integrated systems for control of downy brome (Bromus tectorum) in cropland. Weed Sci. 32(Suppl.)1:26-31.

Wicks, G.A. 1997. Survival of downy brome seed in four environments. Weed Sci. 45:225-228.

Wicks, G.A., O.C. Burnside, and C.R. Fenster. 1971. Influence of soil type and depth of planting on downy brome seeds. Weed Sci. 19:82-86.
Wicks, G.A., D.E. Smika, and G.W. Hergert. 1988. Long-term effects of no-tillage in a winter wheat (Triticum aestivum)-sorghum (Sorghum bicolor)-fallow rotation. Weed Sci. 36:384-393.

Wiese, A.F., C.D. Salisbury, and B.W. Bean. 1995. Downy brome, jointed goatgrass, and horseweed in fallow. Weed Technol. 912: 249-254.

Zuzel, J.F., J.L. Pikul, Jr., and P.E. Rasmussen. 1990. Tillage and fertilizer effects on water infiltration. Soil Sci. Soc. Am. J. 54:205-208.

\title{
Mechanisms of Residue Mulch-Induced Cereal Growth Increases in West Africa ${ }^{1}$
}

\author{
Andreas Buerkert,* André Bationo, and Komlan Dossa
}

\begin{abstract}
The use of crop residues $(\mathrm{CR})$ has been widely reported as a means of increasing crop yields across West Africa. However, little has been done to compare the magnitude and mechanisms of CR effects systematically in the different agro-ecological zones of the region. To this end, a series of field trials with millet (Pennisetum glaucum L.), sorghum [Sorghum bicolor (L.) Moench], and maize (Zea mays L.) was conducted over a 4-yr period in the Sahelian, Sudanian, and Guinean zones of West Africa. Soils ranged in $\mathrm{pH}$ from 4.1 to 5.4 along a rainfall gradient from 510 to $1300 \mathrm{~mm}$. Treatments in the factorial experiments were three CR rates $\left(0,500\right.$, and $\left.2000 \mathrm{~kg} \mathrm{ha}^{-1}\right)$ and several levels of phosphorus and nitrogen. The results showed CR-induced total dry matter (TDM) increases in cereals up to $73 \%$ for the Sahel compared with a maximum of $16 \%$ in the wetter Sudanian and Guinean zones. Residue effects on weakly buffered Sahelian soils were due to improved $P$ availability and to a protection of seedlings against wind erosion. Additional effects of CR mulching on topsoil properties in the Sahel were a decrease in peak temperatures by $4{ }^{\circ} \mathrm{C}$ and increased water availability. These mulch effects on soil chemical and physical properties strongly decreased from North to South. Likely explanations for this decrease are the decline of dust deposition and wind erosion hazards, the higher soil clay content, lower air temperature, and a faster decomposition rate of mulch material with increasing rainfall from the Sahel to the Sudanian and Guinean zones.
\end{abstract}

$\mathrm{L}^{\circ}$ OW AVAILABILITY of mineral nutrients severely limits primary production and particularly crop growth on acid, sandy soils in sub-Saharan West Africa above $300 \mathrm{~mm}$ of annual rainfall (Penning de Vries and van Keulen, 1982; Bationo and Mokwunye, 1991). Given the low clay contents in West African soils and that kaolinite is the dominant clay mineral, soil cation exchange capacity (CEC) mainly depends on the organic carbon content of the topsoil. The current fertility status of these soils may be explained by a number of factors:

A. Buerkert, Institute of Crop Science, Univ. of Kassel, Steinstr. 19, D-37213 Witzenhausen, Germany; A. Bationo, International Fertilizer Development Center (IFDC) at International Crops Research Institute for the Semi-Arid Tropics (ICRISAT) Sahelian Center, B. P. 12404, Niamey, Niger; K. Dossa, IFDC-Africa, B.P. 4483, Lomé, Togo. Joint contribution from Univ. of Hohenheim and ICRISAT Sahelian Ctr., ICRISAT journal article no. 2109. Research supported by the Deutsche Forschungsgemeinschaft (SFB 308). Received 9 Nov. 1998.

*Corresponding author (buerkert@wiz.uni-kassel.de).

Published in Soil Sci. Soc. Am. J. 64:346-358 (2000). age and origin of the soils, leaching, soil erosion by wind and water, short fallow periods, and continued nutrient mining of cropped fields (Stoorvogel and Smaling, 1994).

Under these conditions, application of mineral $\mathrm{N}$ and $P$ fertilizers and even crop residues (CR) surface applied at $2000 \mathrm{~kg} \mathrm{ha}^{-1} \mathrm{yr}^{-1}$ have been reported to cause large yield increases in pearl millet across the southern Sahel (Bationo and Mokwunye, 1991; Bationo et al., 1992, 1993, 1995). For the sub-humid rainforest zones of West Africa with a bimodal annual precipitation of up to $1600 \mathrm{~mm}$, many studies have documented changes in physical and chemical soil parameters as causes for mulch-induced crop growth increases (De Vleeschauwer et al., 1978, 1980; Lal et al., 1980; Maurya and Lal, 1981). However, most of this research was conducted in western Nigeria on moderately sloping Paleustalfs or Luvisols of $\mathrm{pH}>6$. Furthermore, excessive rates of mulch application of up to $24 \mathrm{Mg} \mathrm{ha}{ }^{-1} \mathrm{yr}^{-1}$ were used. For the inner part of West Africa, the northern Guinean, the Sudanian, and the southern Sahelian zones, where annual average rainfall declines from 1300 to $300 \mathrm{~mm}$ and total biomass production is much lower, the causes of CR effects on crop growth and their declining magnitude from North to South are still poorly understood (Bationo et al., 1995). For the Sahel, with its many crust prone sandy soils (Hoogmoed and Stroosnijder, 1984; Valentin and Bresson, 1992), most reported data come from a very limited zone with rainfall ranging between 500 and $600 \mathrm{~mm}$. For this area, mulch effects have been attributed to increased $\mathrm{P}$ availability (Kretzschmar et al., 1991), more vigorous root development (Hafner et al., 1993b), enhanced potassium (K) nutrition (Rebafka et al., 1994), protection of young seedlings against soil coverage during sand storms (Michels et al., 1995b), and a decrease in the penetration resistance of the soil surface that affect emergence and root growth of seedlings (Buerkert and Stern, 1995).

${ }^{1}$ Dedicated to Horst Marschner and his commitment to processoriented soil fertility research in West Africa.

Abbreviations: CAN, calcium ammonium nitrate; CEC, effective cation exchange capacity; $\mathrm{CR}$, crop residues as cereal stover; DAS, days after sowing; NPK, 15-15-15 mineral fertilizer with $15 \% \mathrm{~N}, 15 \% \mathrm{P}_{2} \mathrm{O}_{5}$, and $15 \% \mathrm{~K}_{2} \mathrm{O}$; SSP, single superphosphate; TDM, total dry matter; TRP, Tahoua rock phosphate. 